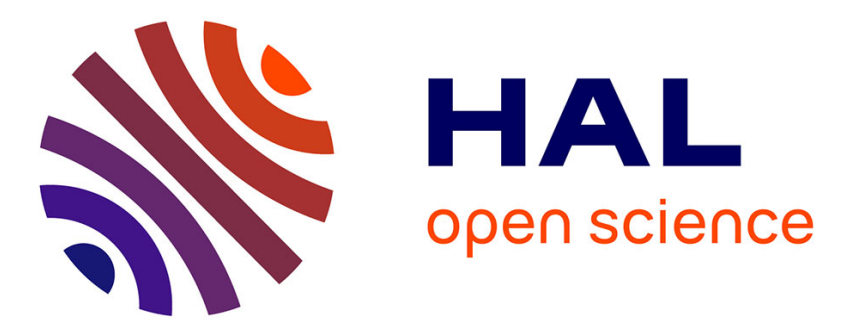

\title{
Glacier decline between 1963 and 2006 in the Cordillera Real, Bolivia
}

\author{
Alvaro Soruco, Christian Vincent, Bernard Francou, J.F. Gonzalez
}

\section{To cite this version:}

Alvaro Soruco, Christian Vincent, Bernard Francou, J.F. Gonzalez. Glacier decline between 1963 and 2006 in the Cordillera Real, Bolivia. Geophysical Research Letters, 2009, 36 (3), pp.L03502. 10.1029/2008GL036238 . insu-00413388

\section{HAL Id: insu-00413388 \\ https://hal-insu.archives-ouvertes.fr/insu-00413388}

Submitted on 24 Mar 2021

HAL is a multi-disciplinary open access archive for the deposit and dissemination of scientific research documents, whether they are published or not. The documents may come from teaching and research institutions in France or abroad, or from public or private research centers.
L'archive ouverte pluridisciplinaire HAL, est destinée au dépôt et à la diffusion de documents scientifiques de niveau recherche, publiés ou non, émanant des établissements d'enseignement et de recherche français ou étrangers, des laboratoires publics ou privés. 


\title{
Glacier decline between 1963 and 2006 in the Cordillera Real, Bolivia
}

\author{
Alvaro Soruco, ${ }^{1,2}$ Christian Vincent, ${ }^{2}$ Bernard Francou, ${ }^{1,2}$ and Javier Francisco Gonzalez ${ }^{3}$ \\ Received 6 October 2008; revised 27 November 2008; accepted 18 December 2008; published 11 February 2009.
}

[1] The volume changes of 21 glaciers in the Cordillera Real have been determined between 1963 and 2006 using photogrammetric measurements. These data form the longest series of mass balances obtained with such accuracy in the tropical Andes. Our analysis reveals that temporal mass balance fluctuations are similar, revealing a common response to climate over the entire studied region. The mass of these glaciers has clearly been decreasing since 1975 without any significant acceleration of this trend over recent years. We have found a clear relationship between the average mass balance of these glaciers as a function of exposure and altitude. From this relationship, the ice volume loss of 376 glaciers has been assessed in this region. The results show that these glaciers lost $43 \%$ of their volume between 1963 and 2006, essentially over the 19752006 period and $48 \%$ of their surface area between 1975 and 2006. Citation: Soruco, A., C. Vincent, B. Francou, and J. F. Gonzalez (2009), Glacier decline between 1963 and 2006 in the Cordillera Real, Bolivia, Geophys. Res. Lett., 36, L03502, doi:10.1029/2008GL036238.

\section{Introduction}

[2] Numerous studies have shown that glaciers are very good indicators of climate change [Intergovernmental Panel on Climate Change, 2007; Oerlemans, 2001]. Glacier mass variations can be very useful to assess climate change over the $20^{\text {th }}$ Century and the beginning of the 21 st Century for such remote regions as the tropical Andes where meteorological data are sparse [Vuille et al., 2008]. Moreover, the glaciers of the tropical Andes make an important contribution to the water resources of many high-elevation basins during the dry season [Ribstein et al., 1995; Mark and Seltzer, 2003]. Unfortunately, available data becomes sparser as we go back in time. Documentation in the tropical Andes over recent decades provides only glacier length or area change observations and only for a limited number of glaciers [Kaser, 2001; Kaser and Osmaston, 2001; Vuille et al., 2008]. As shown in previous studies [Paterson, 1994; Johannesson et al., 1989], these length and area variations cannot be directly interpreted in terms of climate change on an annual or decadal time-scale. Conversely, specific mass balance results directly from climate parameters as they record solid precipitation and surface energy fluxes via ablation [Oerlemans, 2001] and it has been shown that the mass balance fluctuations are a good indicator of climate

\footnotetext{
${ }^{1}$ IRD-LGGE, BP 96, Saint Martin d'Hères, France.

${ }^{2}$ Laboratoire de Glaciologie et de Géophysique de l'Environnement CNRS/UJF, BP 96, Saint Martin d'Hères, France.

${ }^{3}$ Institute of Geography, Heinrich-Heine Universität, Düsseldorf, Germany.
}

Copyright 2009 by the American Geophysical Union. 0094-8276/09/2008GL036238 change [Vincent et al., 2005]. Unfortunately, very few continuous direct mass balance observations are available in this region. The longest series of direct mass balance measurements in the Andean countries is from the Zongo glacier in Bolivia [Soruco et al., 2009] where observations using the glaciological method have been carried out since 1991.

[3] In this paper, mass balance fluctuations of 21 glaciers in the Cordillera Real of Bolivia were measured back to 1963 using photogrammetric data. These glacier mass variations were used to assess the climate change leading to the large recession of Bolivian glaciers since 1975 .

\section{Data}

[4] Figure 1 shows the locations of the studied glaciers in the Cordillera Real, which includes $11 \%$ of all tropical glaciers and $55 \%$ of Bolivian glaciers, representing a surface area of $324 \mathrm{~km}^{2}$ in 1975 [Jordan, 1991]. The Cordillera Real has an approximate length of $180 \mathrm{~km}$ extending in a NW-SE direction and delimiting the wet Amazonas basin in the east and the dry Altiplano basin in the west. Twenty-one glaciers were selected in the Cordillera Real to represent a comprehensive range of size, aspect and elevation. Aerial photographs were taken in 1963, 1975, 1983, 1997 and 2006 by the National Service of Aerophotogrammetry of Bolivia. We have measured eighty-six ground control points using geodetic differential GPS (Global Positioning System) and their positions are known with an uncertainty of $\pm 0.03 \mathrm{~m}$. Photogrammetric measurements based on the 97 aerial photographs acquired in 2006 were made using the bundle block adjustment method with 449 tie points and 73 ground control points. The aerial photographs taken prior to 2006 were triangulated using 59 pairs with a minimum of 20 tie points and 8 ground control points for each pair. These ground control points come from the direct GPS measurements mentioned above and from the photogrammetric measurements of 2006 to improve consistency and accuracy for the calculation of volume variations. To check the photogrammetric results and assess the accuracy of measurements, a cross-section free of ice and snow was measured for each pair of photographs (for each epoch). The comparison reveals altitude differences of less than $2.9 \mathrm{~m}$ with a standard deviation of $0.7 \mathrm{~m}$. The photogrammetric measurements of each glacier for each date have been performed using a digital photogrammetric station (Leica photogrammetry suite) according to irregular grids of $10 \mathrm{~m}$ for rough terrain and $20 \mathrm{~m}$ for flat areas. The Digital Elevation Model (DEM) was obtained from Kriging analysis with a resampling of $10 \mathrm{~m}$. The subtraction of the DEM values yields altitudinal variations that must be converted to water equivalent using Sorge's law [Thibert et al., 2008] and accordingly assuming a density of $\rho=900 \mathrm{~kg} \mathrm{~m}^{-3}$. The volumetric mass balance 


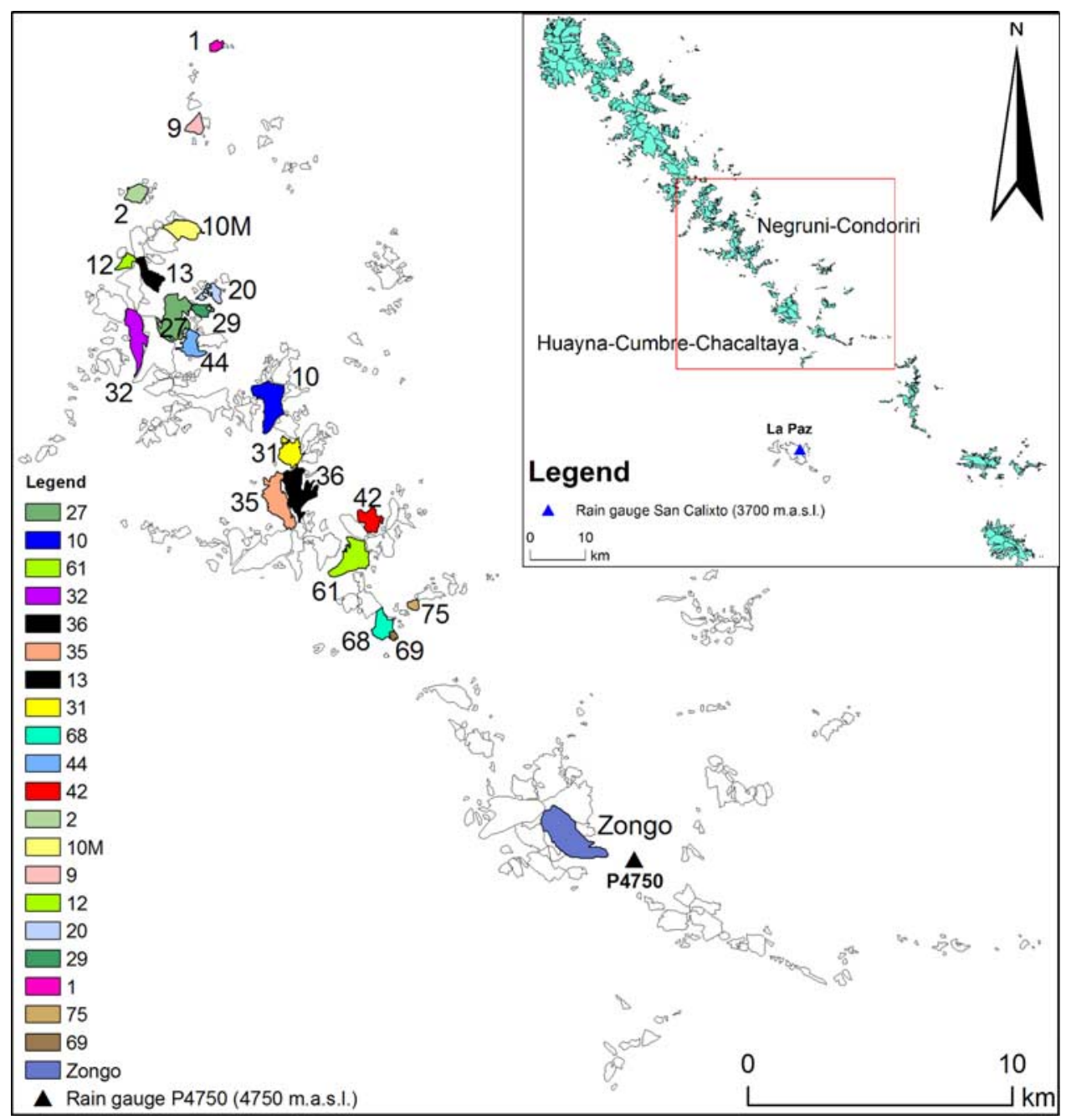

Figure 1. Map of glaciers in the Cordillera Real. The studied area is shown in the red square. Meteorological stations are shown on the map.

is obtained by dividing the mass variation by the mean surface area.

[5] In addition, meteorological data have been used to analyse the causes of mass balance changes over the last decades. Very few long precipitation series are available for the Cordillera Real range. The longest measurement series was started in 1971 by the Bolivian Hydropower Company and corresponds to a rain gauge (P4750) located at $4750 \mathrm{~m}$ a.s.l. close to Zongo glacier (Figure 1). These data have been carefully checked by Ribstein et al. [1995]. Comparison with precipitation measured outside the Cordillera Real, at La Paz, shows a very large spatial gradient. For instance, the average P4750 annual precipitation is $857 \mathrm{~mm}$ w.e. (1972-2006) although the annual precipitation at San Calixto (3700 m a.s.l., La Paz city) is $595 \mathrm{~mm}$ w.e. (19722006), $30 \mathrm{~km}$ away. Note that most precipitation comes from the eastern interior of the continent [Garreaud, 1999]. Furthermore, $84 \%$ of precipitation measured at P4750 falls during the austral summer between October and March, and 68\% between December and March. Long direct temperature series are not available within the Cordillera Real. Direct temperatures are available at the city of El Alto (4071 m a.s.l., $5 \mathrm{~km}$ from La Paz) only back to 1968.
Consequently, the reanalysed (NCEP-NCAR) data at $500 \mathrm{hPa}$ [Kalnay et al., 1996] have been used. Note the good correlation between these data and direct temperatures measured at Alto between 1968 and $2006\left(R^{2}=0.84\right)$ for the December-March period that controls to a major extent the interannual mass balance variability [Francou et al., 2003].

\section{Data Analysis}

[6] As depicted in Figure 2a, cumulative mass balances of these 21 glaciers come from photogrammetric measurements extending back to 1963. Annual mass balance reconstruction from hydrological data and direct measurements provide additional volume variation estimates back to 1972 for the Zongo glacier [Soruco et al., 2009]. Figure 2a shows that these 21 glaciers have been receding over the last 43 years. Figure $2 \mathrm{a}$ shows two main features. First, the averaged cumulative mass balances are very different from place to place and range from $-0.26 \mathrm{~m}$ w.e. $\mathrm{a}^{-1}$ to $-1.38 \mathrm{~m}$ w.e. $\mathrm{a}^{-1}$. Second, the negative trend is not regular with time. The negative mass balance occurs clearly after 1975 for all glaciers. Several of these glaciers experienced a slight mass 

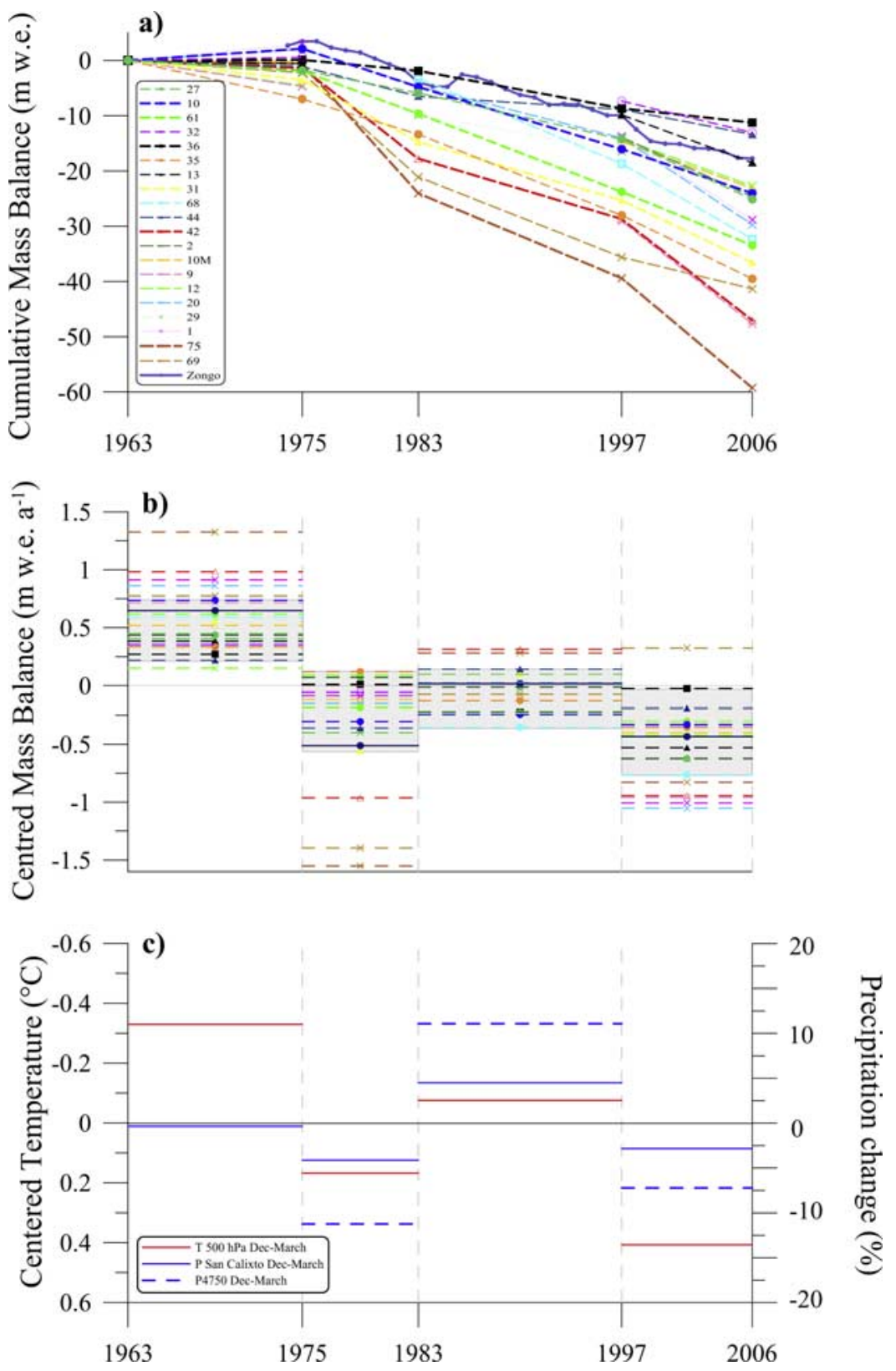

Figure 2. (a) Cumulative mass balances of 21 glaciers in the Cordillera Real, over the period 1963-2006. (b) Centred annual mass balance $\left(\mathrm{m}\right.$ w.e. $\left.\mathrm{yr}^{-1}\right)$. (c) Centred temperatures and precipitation changes $(\%)$ over the December-March period.

gain over the 1963-1975 period. The differences between each glacier result mainly from their respective geometric characteristics, especially altitude and exposure as shown below. In order to investigate the mass balance fluctuations with time alone, the average rate of decrease has been removed. Subtracting the last 43-year average mass balance of each glacier from the annual values provides centred annual mass balances for each period (Figure $2 b$ ). The grey part shows the centred mass balance for glaciers larger than $0.4 \mathrm{~km}^{2}$. It reveals good consistency for these data from glaciers spread over $600 \mathrm{~km}^{2}$ of the Cordillera Real. The error of the photogrammetric results has been analysed using the method proposed by Thibert et al. [2008]. The maximum errors on the cumulative mass balance obtained from photogrammetric data are estimated at 1.5, 2.4, 3.5 and $3.7 \mathrm{~m}$ w.e. over the $1963-1975,1975-1983,1983-1997$ and 1997-2006 periods, respectively [Soruco et al., 2009]. This leads to errors of $0.11,0.27,0.23$ and $0.37 \mathrm{~m}$ w.e. $\mathrm{a}^{-1}$ on the centred annual mass balance for each period, respectively. The dispersion of data contained in the grey parts therefore hardly exceeds the uncertainty of the measurements. Conversely, several of the smallest glaciers (areas $<0.4 \mathrm{~km}^{2}$ ) differ from the fluctuation pattern shown in grey. Note that the mass balance fluctuations of the smallest glaciers can be strongly affected by local conditions. For instance, the volume variations of very small glaciers are influenced by "edge effects" which tend to accelerate glacier retreat during negative mass balance 


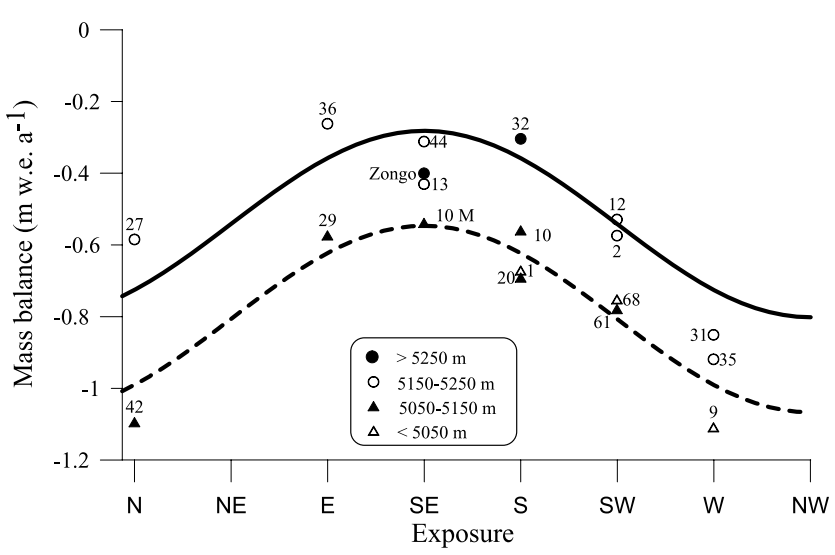

Figure 3. Mean observed mass balances (1963-2006) on 21 glaciers versus exposure. The large dots correspond to glaciers with mean altitudes above $5150 \mathrm{~m}$ and the small dots to glaciers below $5150 \mathrm{~m}$. The continuous and dashed lines result from the equation given in the text for altitudes of 5300 and $5150 \mathrm{~m}$, respectively.

periods [Vuille et al., 2008]. On the other hand, an increase in the thickness of surface debris tends to reduce melting and glacier retreat. Moreover, as shown in studies performed on the Zongo glacier [Soruco et al., 2009], surface mass balance variability is larger at low altitudes in the ablation area. This should result in higher variability for low-lying glaciers that experienced negative mass balances most of the time over recent decades. Figure $2 b$ seems to confirm this result although local effects mentioned above could partly mask this influence. Note that the smallest glacier, no. 69, with an area of $0.006 \mathrm{~km}^{2}$ in 2006, experienced, during the last period, a mass balance exceeding the 1963-2006 average. In fact, the thickness of the glacier in 1997 was less than the melting that occurred between 1997 and 2006 on most of its surface. On the whole, Figure $2 b$ reveals a common climatic signal over the entire region. This result confirms the observations performed on two glaciers located $20 \mathrm{~km}$ apart, Chacaltaya and Zongo, over a shorter period extending from 1991 to 2001 [Francou et al., 2003, Figure 5]. In order to determine the origin of this signal, the mass balance fluctuations have been compared with precipitation and temperature changes in this region. Previous studies carried out on Zongo and Chacaltaya glaciers [Wagnon et al., 2001; Sicart, 2002; Francou et al., 2003] have shown that the glacier mass balance is mainly controlled by the mass balance variations during the summer months which correspond to the wet season. Measurements over the Zongo glacier show that the four summer months (December-March) account for $70 \%$ of the total variance of the annual mass balance. Considering that this period holds the key to explaining the interannual mass balance variability, precipitation and temperature data of these months have been selected for our analysis. Averaged centred precipitation and reanalysed temperatures (December to March) are plotted in Figure 2c for each period. Centred precipitation data have been divided by the 1963-2006 mean precipitation and are expressed in percent. Data from P4750 have been centred according to the 1972-2006 period, given that measurements started in 1971. Note that 1963-2006 and 1975-2006 mean precip- itations are the same at San Calixto. The temperature scale is positive downward in order to be consistent with the mass balance sign. Some overall features can be observed in Figure 2c. First, warm (cold) periods correspond to dry (wet) periods, as shown by Vuille et al. [2000]. Second, precipitation variability at this time scale is very low and precipitation differences do not exceed $\pm 11 \%$. Thus, mass balance variability and precipitation variability differ by almost an order of magnitude. A change in precipitation of less than $70 \mathrm{~mm}$ cannot directly explain changes in mass balances larger than $500 \mathrm{~mm}$. Considering that the precipitation lapse rate is small [Sicart et al., 2007], it would be tempting to conclude that the influence of precipitation on mass balance is low. However, as shown in previous studies [Wagnon et al., 2001; Sicart, 2002], the feedback on albedo induced by solid precipitation is more significant in explaining the large variability of annual glacier mass balance than the annual variability of accumulation itself. Indeed, although precipitation is weak, a thin snow cover of high albedo is sufficient to stop an intense melting. Based on a detailed meteorological and mass balance analysis of Zongo Glacier, Favier et al. [2004] conclude that the inter-annual variability of the mass balance of this glacier mostly depends on the inter-annual variability of the precipitation especially during the crucial December-January period. Although the detailed analysis of the relationships between mass balance and meteorological parameters is beyond the scope of our study, Figures $2 \mathrm{~b}$ and $2 \mathrm{c}$ show a rough agreement between mass balance variations and temperature/precipitation variations. However, these data do not allow us to determine which parameter controls the mass balance change. In any case, note that the interannual mass balance variability, shown for Zongo Glacier (Figure 2a), greatly exceeds the decadal variability. For instance, the mass loss of Zongo over the two years 1997-1999 corresponds to $60 \%$ of the 1997-2006 loss (Figure 2a) and reveals that annual mass balances are strongly affected by ENSO events [Wagnon et al., 2001].

[7] Furthermore, the differences in cumulative mass balance of the 21 glaciers have been analysed. Contrary to the temporal fluctuations in mass balance which are strongly related to climate change, mean mass balance depends mainly on geometric parameters [Paterson, 1994, p. 42]. We have found that the differences of cumulative mass balance trends, shown in Figure 2a, can be largely explained by the mean altitude and exposure of each glacier. The mean mass balances of the 1963-2006 period are plotted in Figure 3 against exposure, by separating the glaciers according to the mean altitude of each glacier. The smallest glaciers (no. 75 and 69) with surface areas $<0.03 \mathrm{~km}^{2}$ in 2006 were excluded as they are disappearing. The mean altitudes have been calculated using the digital elevation model of each glacier in 1963. Figure 3 reveals that glaciers with exposure between east and south experienced less negative mass balances. Also, the mass balances of the highest glaciers are less negative. This pattern can be partly related to the tropical location of these glaciers $\left(16^{\circ} 0^{\prime}-\right.$ $16^{\circ} 22^{\prime} \mathrm{S}$ ), where the mean incident solar radiation is higher for northern exposure throughout most of the year. The origin of the very negative mass balances of glaciers with western exposure could be explained by the accumulation difference on eastern and western exposures considering 
that most of the precipitation comes from the east. According to the results shown in Figure 3, we performed a linear multiple regression analysis with mass balance as the dependent variable and altitude and exposure as independent predictors. We checked that the altitude and exposure variables were not dependent $\left(\mathrm{R}^{2}=0.07\right)$. We performed a stepwise forward elimination procedure, where variables that explain a significant amount of variance in the presence of other factors at the 95\%-confidence level, based on an Ftest, are retained in the model. Our results indicate that both altitude and exposure explain a significant amount of variance $\left(R^{2}=0.88\right)$. The results show that the mean annual mass balances of 1963-2006 for each glacier can be expressed by $0.00106 Z-0.25840 \sin (E+135)-6.16$, where $\mathrm{Z}$ is the mean altitude $(\mathrm{m})$ in 1963 and $\mathrm{E}$ the exposure $\left({ }^{\circ}\right)$. Given that the mean altitude and exposure of each glacier did not change significantly between 1963 and 1975, this relationship remains unchanged with 1975 data. Using the mean altitude and the exposure of glaciers determined in 1975 in the Cordillera Real [Jordan, 1991], it becomes possible to calculate the ice mass loss of 376 glaciers over the whole study area (which is $11 \%$ of the glaciated areas in the Cordillera Real). The results show that this region lost $0.9 \mathrm{~km}^{3}$ of ice between 1963 and 2006. Moreover, the volume of each glacier has been assessed from volumearea scaling [Bahr et al., 1997] revealing that these glaciers have lost $43 \% \pm 20 \%$ of their volume. Finally, photogrammetric data have been used to obtain the surface area and length changes of each glacier. For this purpose, the surface areas of these 376 glaciers were determined from photogrammetric data for 2006 and compared with those of 1975. It reveals that these glaciers lost $48 \% \pm 5 \%$ of their surface area between 1975 and 2006.

[8] In addition, our measurements relative to the sample of 21 glaciers over the 1963-2006 period show that the area changes are poorly related to mass balance over each period $\left(\mathrm{R}^{2}<0.15\right)$ and over the whole period $\left(\mathrm{R}^{2}=0.08\right)$. Detailed measurements of area/length changes on the Zongo glacier [Vuille et al., 2008] lead to the same conclusion. Indeed, the strong retreat observed over the 1992-2006 period compared to the 1963-2006 average does not reflect the mass balance evolution. This confirms that area or length changes are poor indicators for climate change analysis at a decadal time-scale.

\section{Conclusions}

[9] Our study has allowed us to obtain the longest series of glacier volume change in the tropical Andes with an accuracy of 0.1 to $0.4 \mathrm{~m}$ w.e. $\mathrm{yr}^{-1}$. These cumulative mass balances obtained from photogrammetric measurements of 21 glaciers over the 1963-2006 period indicate a marked downtrend since 1975 in the Cordillera Real. Centred mass balance analysis over four periods between 1963 and 2006 shows that temporal mass balance fluctuations are similar, revealing a common response to climate over the entire studied region, except for the smallest glaciers which can be strongly affected by local conditions.

[10] The cumulative mass balances of these glaciers do not show any acceleration of the trend. The strong retreat of the Zongo snout observed over the 1992-2006 period does not reflect the mass balance changes of this glacier. Al- though our dataset does not allow us to clearly link the mass balance variations with precipitation and temperature variations, mass balance variations observed at a decadal scale are roughly in agreement with temperature and precipitation changes.

[11] The differences of the cumulative mass balance trends observed over the 1963-2006 period can be explained to a large extent by the exposure and altitude of each glacier. The highest glaciers and glaciers with exposures between east and south experienced less negative mass balances. Using the strong relationship found between mass balance, exposure and altitude, the ice volume loss of 376 glaciers assessed in this region over the period $1963-$ 2006 , corresponds to $43 \%$ of their volume. In addition, our surface area measurements of these 376 glaciers indicate an overall shrinkage in glacier area of $48 \%$ between 1975 and 2006.

[12] In the future, these results will be used to assess the impact of glaciers shrinkage on water runoff, especially for La Paz city.

[13] Acknowledgments. The GREATICE glaciological program is supported by l'Institut de Recherche pour le Développement (IRD) and by the French ORE Programme GLACIOCLIM (http://www-lgge.ujfgrenoble.fr/ServiceObs/index.htm). We thank Abraham Machaca, Javier Mendoza, Lars Ungerechts, Ekkehard Jordan and Renaud Blanc for their data and comments. We are grateful for the assistance of IHH (Instituto de Hidráulica e Hidrología) and COBEE (Compania Boliviana de Energía Eléctrica) in La Paz. We are grateful to the anonymous reviewers whose comments improved the quality of the manuscript.

\section{References}

Bahr, D. B., M. F. Meier, and S. D. Peckham (1997), The physical basis of glacier volume-area scaling, J. Geophys. Res., 102, 20,355-20,362.

Favier, V., P. Wagnon, and P. Ribstein (2004), Glaciers of the outer and inner tropics: A different behaviour but a common response to climatic forcing, Geophys. Res. Lett., 31, L16403, doi:10.1029/2004GL020654.

Francou, B., M. Vuille, P. Wagnon, J. Mendoza, and J. E. Sicart (2003), Tropical climate change recorded by a glacier in the central Andes during the last decades of the twentieth century: Chacaltaya, Bolivia, $16^{\circ} \mathrm{S}, J$. Geophys. Res., 108(D5), 4154, doi:10.1029/2002JD002959.

Garreaud, R. (1999), Intraseasonal variability of moisture and rainfall over the South American Altiplano, Mon. Weather Rev., 128, 3337-3346.

Intergovernmental Panel on Climate Change (2007), Climate Change 2007: The Physical Science Basis, Contribution of Working Group I to the Fourth Assessment Report of the Intergovernmental Panel on Climate Change, edited by S. Solomon et al., Cambridge Univ. Press, U.K.

Johannesson, T., C. Raymond, and E. Waddington (1989), Time-scale for adjustment of glaciers to changes in mass balance, J. Glaciol., 35, 355369.

Jordan, E. (1991), Die Gletsher der Bolivianischen Anden, 401 pp., Franz Steiner, Stuttgart, Germany

Kalnay, E., et al. (1996), The NCEP/NCAR 40-year reanalysis project, Bull. Am. Meteorol. Soc., 77, 437-471.

Kaser, G. (2001), Glacier-climate interaction at low latitudes, J. Glaciol., 47, 195-204.

Kaser, G., and H. Osmaston (2001), Tropical Glaciers, 206 pp., Cambridge Univ. Press, Cambridge, U.K.

Mark, B. G., and G. O. Seltzer (2003), Tropical glacier meltwater contribution to stream discharge: A case study in the Cordillera Blanca, Peru, J. Glaciol., 49, 271-281.

Oerlemans, J. (2001), Glaciers and Climate Change, 148 pp., R. R. Balkema, Rotterdam, Netherlands.

Paterson, W. S. B. (1994), The Physics of Glaciers, 3rd ed., 480 pp., Pergamon, New York.

Ribstein, P., E. Tiriau, B. Francou, and R. Saravia (1995), Tropical climate and glacier hydrology: A case study in Bolivia, J. Hydrol., 165, 221-234.

Sicart, J. E. (2002), Contribution à l'étude des flux d'energie, du bilan de masse et du debit de fonte d'un glacier tropical: Le Zongo, Bolivie, Ph.D. thesis, 347 pp., Univ. Paris VI - Pierre et Marie Curie, Paris, France.

Sicart, J. E., P. Ribstein, B. Francou, B. Pouyaud, and T. Condom (2007), Glacier mass balance of tropical Zongo glacier, Bolivia, comparing hydrological and glaciological methods, Global Planet. Change, 59, 27-36. 
Soruco, A., C. Vincent, B. Francou, P. Ribstein, T. Berger, J. E. Sicart, P. Wagnon, Y. Arnaud, V. Favier, and Y. Lejeune (2009), Mass balance of Zongo Glacier, Bolivia, between 1956 and 2006, using glaciological, hydrological and geodetic methods, Ann. Glaciol., 50, in press.

Thibert, E., R. Blanc, C. Vincent, and N. Eckert (2008), Glaciological and volumetric mass balance measurements: Error analysis over 51 years for Glacier de Sarennes, French, Alps, J. Glaciol., 54, 522-532.

Vincent, C., E. LeMeur, D. Six, and M. Funk (2005), Solving the paradox of the end of the Little Ice Age in the Alps, Geophys. Res. Lett., 32, L09706, doi:10.1029/2005GL022552.

Vuille, M., R. S. Bradley, and F. Keimig (2000), Interannual climate variability in the Central Andes and its relation to tropical Pacific and Atlantic forcing, J. Geophys. Res., 105, 12,447-12,460.
Vuille, M., B. Francou, P. Wagnon, J. Irmgard, G. Kaser, B. G. Mark, and R. S. Bradley (2008), Climate change and tropical Andean glaciers: Past, present and future, Earth Sci. Rev., 89, 79-96.

Wagnon, P., P. Ribstein, B. Francou, and J. E. Sicart (2001), Anomalous heat and mass budget of Glaciar Zongo, Bolivia, during the 1997/98 El Niño year, J. Glaciol., 47, 21-28.

B. Francou and A. Soruco, IRD-LGGE, BP 96, F-38402 Saint Martin d'Hères, France.

J. F. Gonzalez, Institute of Geography, Heinrich-Heine Universität, D-40225 Düsseldorf, Germany.

C. Vincent, Laboratoire de Glaciologie et de Géophysique de l'Environnement CNRS/UJF, BP 96, F-38402 Saint Martin d'Hères, France. (christian.vincent@lgge.obs.ujf-grenoble.fr) 